\title{
Reflections on Blended Learning: A Case Study at the Open University of Hong Kong
}

\section{Anna Wing Bo Tso*}

School of Arts and Social Sciences, The Open University of Hong Kong, China

\begin{abstract}
Teaching presentation skills is by no means an easy task. To teach such skills effectively, a teacher must help the students to learn how to (1) design and organize the presentation content effectively; (2) strengthen their verbal and nonverbal communication skills; and (3) master the use of visual aids. Often, the traditional face-to-face classroom setting falls short when the lecturer has to teach more than 100 students how to observe small details of body language and vocal skills. In this case, a blended learning mode - a hybrid of face-to-face and online learning may be a better option than a pure face-to-face learning mode (Fang, Chow \& Soo, 2012).
\end{abstract}

The purpose of this paper is to demonstrate how blended learning can be implemented to teach university students' presentation skills. In the spring term of 2013, ENGL A122F: Presentation Skills, a five-credit course for full-time undergraduate students, was first delivered via a blended learning approach at the Open University of Hong Kong. Attempting to combine the best features of the online and face-to-face modes of teaching, the blended delivery course incorporated video and interactive web-based components into the course outline.

In this paper, I share my experience of how presentation skills can be taught through video lectures and assessed through the online learning environment (OLE), alongside traditional teacher-led lectures and tutorials. Also, I discuss how the blended learning approach, compared with the traditional face-to-face teaching mode, can not only facilitate propositional knowing, but also help learners to achieve experiential knowing, and presentational knowing (Heron \& Reason, 2006). Last but not least, the paper reflects on students' feedback, as well as the challenges when implementing the blended learning mode.

Keywords: blended learning, presentation skills, higher education, experiential knowing, presentational knowing

\section{Introduction to Blended Learning}

Blended learning, an increasing popular teaching approach in the digital age, is a systematic way of combining the best features of face-to-face classes and

\footnotetext{
${ }^{*}$ Corresponding author. Email: atso@ouhk.edu.hk
} 
online/distance learning. According to Krase (2007, cited in Bath and Bourke, 2013:

Blended learning is realized in teaching and learning environments where there is an effective integration of different modes of delivery, modes of teaching and style of learning as a result of adopting a strategic and systematic approach to the use of technology combined with the best features of face to face interaction (p. 1).

A blended course design, development and delivery mode provides flexibility in terms of assignment submission, assessment methods, group work transparency, marking, feedback, the release of grades, and communication between students and teachers. The most popular blended learning tools employed by universities worldwide include blogs, Twitter, discussion boards, e-assessment, e-portfolios, live Internet streaming, video conferencing, mobile device apps, MOOCs, and open educational resources (OERs). All of these tools enrich the student learning experience and optimize student engagement, as well as improving the course administration and management through the use of information and communication technologies (ICT). Overall, the blended learning approach has opened up endless learning possibilities for the Net generation.

\section{A Blended Learning Case Study at the Open University of Hong Kong}

At the Open University of Hong Kong, blended learning has also been implemented in the curriculum. ENGL A122F Presentation Skills is one example. As a five-credit, one-semester course for full-time face-to-face students, ENGL A122F aims to provide learners with a practical approach to mastering face-to-face presentation effectively. Within the duration of 13 weeks, the lecturer has to teach the following areas to over 100 students:

Table 1 Topics to be covered in ENGLA A122F

\begin{tabular}{cl}
\hline & \multicolumn{1}{c}{ Topics } \\
\hline 1. & Why do we need presentation skills? \\
\hline 2. & What is communication? \\
\hline 3. & Barriers to communication \\
\hline 4. & Analysing the situation \\
\hline 5. & Building your presentation \\
\hline 6. & Structuring your presentation \\
\hline 7. & Communicating effectively \\
\hline 8. & Managing body language \\
\hline 9. & Managing your voice \\
\hline 10. & Visual aids \\
\hline 11. & Devices and technologies for displaying visual aids \\
\hline 12. & Setting the stage \\
\hline
\end{tabular}


One headache faced by the lecturer was that it was difficult to teach topics such as 'managing body language' and 'managing your voice' in a lecture room with more than 100 students. Should the lecturer demonstrate certain body language in class in order to explain what effective nonverbal communication is? How about facial expressions? How could the lecturer make sure that students sitting in the back rows of the lecture room see clearly the facial expression demonstrated on his/her face? Also, because of the large class size and inflexible seating arrangement in the lecture theatre, the face-to-face learning mode does not support quality reflective and collaborative learning.

To encourage active learning, the teacher should find ways to help the students see the point of learning, realize how the course is related to them as individuals, and learn how to develop and improve their presentation skills. Learning can become more effective if the teacher can enhance the four ways of knowing via cooperative inquiry (Heron \& Reason, 2006):

1. Propositional knowing: This is the knowing of facts through ideas and theories. This kind of knowing is also the commonest kind that occurs in traditional learning processes.

2. Experiential knowing: This is the direct encounter with a person, place, and/or event. Experiential knowing is achieved when the transformation of experience takes place. Deeper learning and understanding can be enhanced if learners are provided with opportunities to connect with one another, and share and discuss learning experience in an organized way.

3. Presentational knowing: Grounded on experiential knowing, presentational knowing encompasses intuition and reflection, imagination and conceptual thinking (Heron, 1992, p. 158). It reflects the ability to verbalize explicit knowledge and represent tacit knowledge. The form of expression may not be limited to linguistic articulation. Other 'expressive forms of aesthetics, such as drama, movement, story and dance' can also be included (Murphy, 2012, p. 10).

4. Practical knowing: Simply put, practical knowing means knowing how to exercise a skill and do something. It shows the learners' ability to apply what they have learned to accomplish something. Through practical knowing, one puts something into action and finds out how to do things better.

Among the four ways of knowing, propositional knowing can mostly occur in traditional face-to-face lectures. In ENGLA122F, communication theories can be taught in face-to-face lectures. Practical knowing can also occur in face-to-face tutorial sessions, where students' individual and group presentations are assessed by the teacher. Experiential knowing, however, extends beyond the teacher-led lectures and tutorials. For example, how can the teacher make sure that alongside classroom teaching, there is a solid platform for students to connect with one another, and share and discuss their understanding through ideas which make sense to them? Likewise, it is not always easy to allow presentational knowing. In ENGLA122F, while students do have chances to 
practise doing presentations, what is at issue is whether they have the room to verbalize what they have gained through the presentation experiences. Students need a platform where they can reflect on and express their views regarding their presentation experiences, so as to develop the ability to look at their own presentation performance critically. With a view to creating a better learning environment that enhances experiential knowing and presentational knowing, in 2013, the blended learning mode was introduced to ENGL A122F.

\section{The ENGLA122F Blended Learning Experience}

Blended learning can be broadly defined as 'any combination of different methods of learning, different learning environments, different learning styles' that aims to 'achieve the optimal learning environment' (Marsh, 2012, pp. 3-4). For the ENGLA101F teaching team, blended learning, as Solomon and Schrum (2010) point out, offers an online learning arena that allows students to share their experience and provide each other with feedback. Thus, the traditional course framework of ENGLA122F was re-structured. Now, 70\% of the course is delivered via face-to-face lectures and tutorials; and $30 \%$ through online video lectures, recorded presentations with commentaries, brief study questions and assessments, as well as the discussion board. Self-directed learning is encouraged among students, who take the initiative to learn on their own by watching recorded lessons and presentations, listening to commentaries on speeches, and interacting through the discussion board in the Online Learning Environment (OLE).

As shown in Table 2 and Figure 1, face-to-face lectures on body language, facial expressions and vocal skills are now replaced by online videos with close-up demonstrations and explanation. With the 'freeze' and 'replay' functions, learners can watch the demonstrations closely, learn how to pick up clues from the body language, and interpret the speaker's intention and feelings accordingly. They can also do their revision by replaying the video lectures anytime they need them. In addition, to the advantage of second language learners, text alternatives such as English subtitles and captions are provided alongside the recorded speech in the online video lectures. 
Table 2 ENGLA A122F in the blended learning mode

\begin{tabular}{|c|c|c|c|c|c|}
\hline \multirow[t]{2}{*}{ Week } & \multirow[t]{2}{*}{ Topics } & \multicolumn{2}{|c|}{$\begin{array}{c}\text { Face-to-face study } \\
\text { hours }\end{array}$} & \multicolumn{2}{|c|}{ E-learning hours } \\
\hline & & Lecture & Tutorial & $\begin{array}{c}\text { Multimedia } \\
\text { (e.g. online discussion } \\
\text { and activities, } \\
\text { simulation) } \\
\end{array}$ & $\begin{array}{l}\text { Video/ } \\
\text { audio }\end{array}$ \\
\hline 1 & $\begin{array}{l}\text { Why do we need } \\
\text { presentation skills? }\end{array}$ & & 1 & 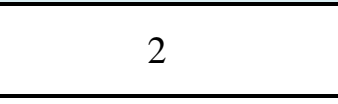 & 1 \\
\hline 2 & What is communication? & & 1 & 3 & 1 \\
\hline 3 & Barriers to communication & 2 & 2 & & \\
\hline 4 & Analysing the situation & 2 & 2 & & \\
\hline 5 & Building your presentation & 2 & 2 & & \\
\hline 6 & $\begin{array}{l}\text { Structuring your } \\
\text { presentation }\end{array}$ & & & 2 & 1 \\
\hline 7 & Communicating effectively & 2 & 2 & & \\
\hline 8 & Managing body language & 2 & & 2 & 1 \\
\hline 9 & Managing your voice & & 2 & 2 & 1 \\
\hline 10 & Visual aids & 2 & 2 & & \\
\hline 11 & $\begin{array}{l}\text { Devices and technologies } \\
\text { for displaying visual aids }\end{array}$ & & 2 & & \\
\hline 12 & Setting the stage & 2 & 2 & & \\
\hline 13 & Revision & 2 & 2 & & \\
\hline & Total hours & & & 16 & \\
\hline & Total percentage & & & $30 \%$ & \\
\hline
\end{tabular}

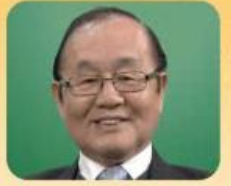

Happiness

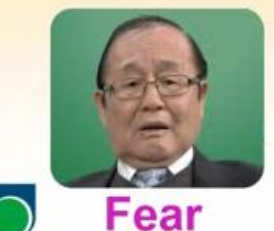

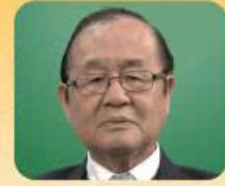

Sadness

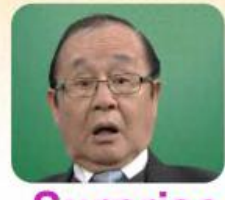

Surprise

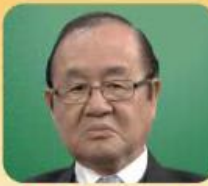

Disgust

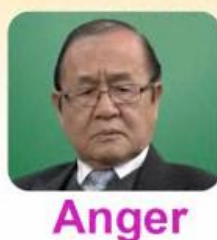

$-\infty$

Figure 1 An online video lecture on non-verbal communication (C) The Open University of Hong Kong. All rights reserved. 
Alongside online video lectures, recorded presentations and the discussion board, for some particular topic areas — such as 'What is communication?' and 'Structuring your presentation' - there are interactive online writing tasks where students share their answers with the ENGL A122F learning community. By using this online platform, called Wiki, the tutor can provide instant feedback on each student's work (see Figure 2). Also, classmates in the same tutorial group can read, write comments, and give feedback on one another's written assignment once it is uploaded onto the Wiki.

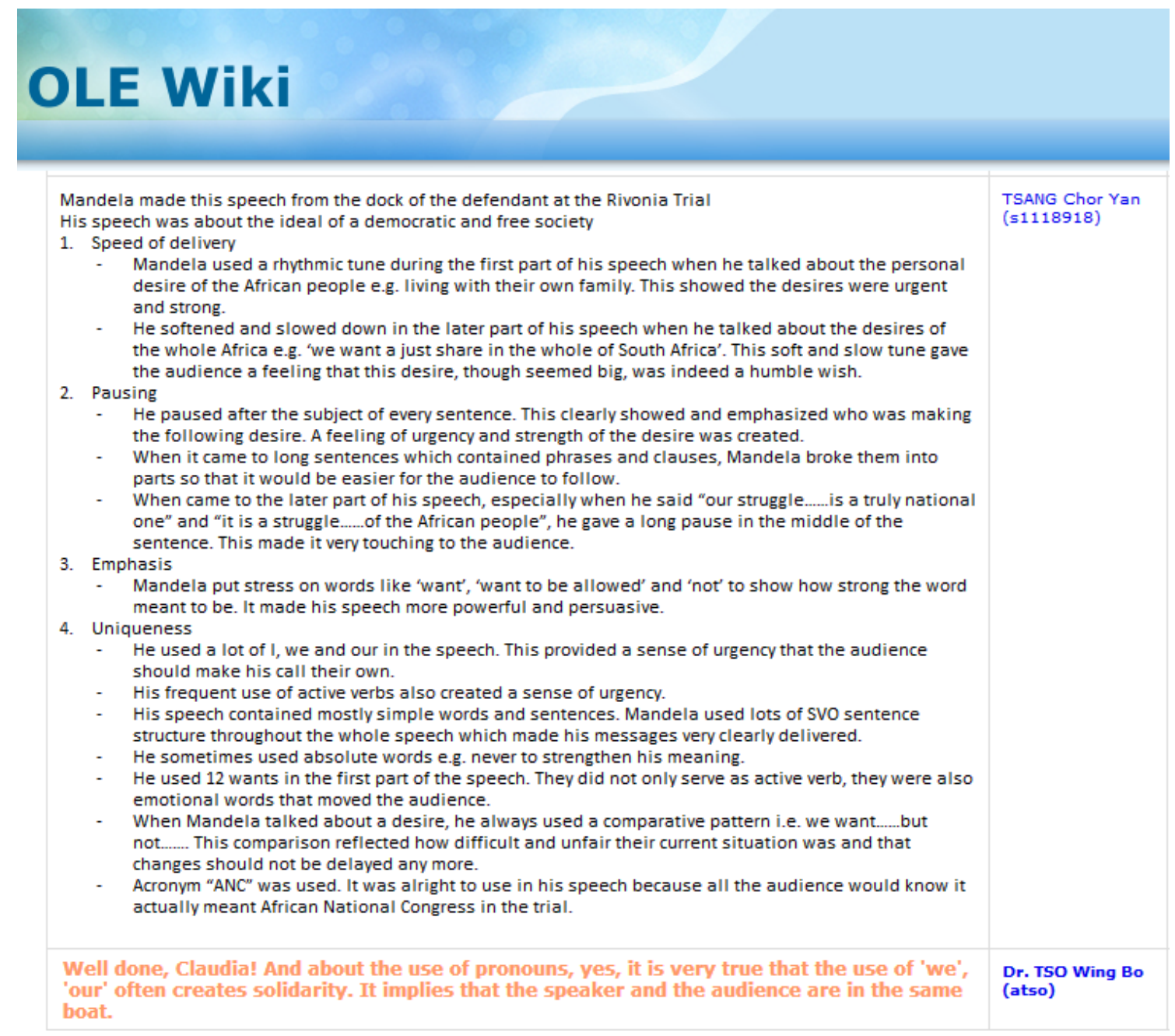

Figure 2 Student-teacher interaction in the Wiki system

(c) The Open University of Hong Kong. All rights reserved.

Meaningful interaction and effective peer collaboration which cannot be achieved in the classroom setting are now supported by the online Wiki platform. Students are able to acquire the knowledge and skills they need for presentation in a more effective and efficient manner. 


\section{Data Analysis and Evaluation for Blended Learning}

After launching the blended learning mode of ENGL A122F in April 2013, I conducted a student survey to check my students' views on blended learning in the course. From the 94 questionnaires gathered from my class, up to $64 \%$ of the students found the online class content, online peer discussion and instant tutor feedback on the Wiki platform helpful in strengthening their understanding of the curriculum content (see Table 4).

Table 3 Survey results that reflect on propositional knowing enhancement

\begin{tabular}{|c|c|c|c|c|c|}
\hline & $\begin{array}{c}\text { Strongly } \\
\text { agree }\end{array}$ & Agree & Neutral & Disagree & $\begin{array}{l}\text { Strongly } \\
\text { disagree }\end{array}$ \\
\hline $\begin{array}{l}\text { 1. The online content enriched } \\
\text { my understanding of key } \\
\text { concepts. }\end{array}$ & $\begin{array}{c}19.2 \% \\
(18)\end{array}$ & $\begin{array}{c}36.2 \% \\
(34)\end{array}$ & $\begin{array}{c}29.8 \% \\
(28)\end{array}$ & $\begin{array}{c}13.8 \% \\
(13)\end{array}$ & $\begin{array}{l}1 \% \\
\text { (1) }\end{array}$ \\
\hline $\begin{array}{l}\text { 2. The peer-discussion and } \\
\text { instant feedback on Wiki } \\
\text { improved my understanding } \\
\text { of the class content. }\end{array}$ & $\begin{array}{c}10.6 \% \\
(10)\end{array}$ & $\begin{array}{c}55.3 \% \\
(52)\end{array}$ & $\begin{array}{c}27.7 \% \\
(26)\end{array}$ & $\begin{array}{c}6.4 \% \\
(6)\end{array}$ & $\begin{array}{l}0 \% \\
(0)\end{array}$ \\
\hline
\end{tabular}

The student feedback recorded in the end-of-course evaluation report also reflected that students found the online video lectures useful and interesting (see Table 4). Propositional knowing was enhanced.

Table 4 Excerpted student feedback on the ENGLA122F video lectures

\begin{tabular}{|ll|}
\hline Feedback 1. & $\begin{array}{l}\text { 'It's interesting to watch videos. This helps me to know about the content of } \\
\text { the course.' }\end{array}$ \\
\hline Feedback 2. & $\begin{array}{l}\text { 'Some of the OLE videos are quite interesting and help me to have a better } \\
\text { understanding of presentation provided with key teaching points. }\end{array}$ \\
\hline Feedback 3. & 'Useful video showing what a good presentation should be.' \\
\hline Feedback 4. & 'The course includes a lot of videos that demonstrate different points.' \\
\hline
\end{tabular}

Students also found the online exercises in Wiki and peer discussion in the OLE useful for their learning. The post-course survey revealed that more than half of the ENGLA122F classmates 'agreed' or 'strongly agreed' that with the introduction of the blended learning approach, they became connected more closely to their classmates in the course, which in turn enhanced peer learning and reflective thinking. Experiential knowing was enhanced. 
Table 5 Survey results that reflect on experiential knowing enhancement

\begin{tabular}{|c|c|c|c|c|c|}
\hline & $\begin{array}{c}\text { Strongly } \\
\text { agree }\end{array}$ & Agree & Neutral & Disagree & $\begin{array}{l}\text { Strongly } \\
\text { disagree }\end{array}$ \\
\hline $\begin{array}{l}\text { 3. I feel more connected with } \\
\text { my fellow classmates in this } \\
\text { course. The online component } \\
\text { encouraged peer learning and } \\
\text { reflective thinking. }\end{array}$ & $\begin{array}{c}13.8 \% \\
(13)\end{array}$ & $\begin{array}{c}37.2 \% \\
(35)\end{array}$ & $\begin{array}{c}37.2 \% \\
(35)\end{array}$ & $\begin{array}{c}5.4 \% \\
(5)\end{array}$ & $\begin{array}{c}6.4 \% \\
(6)\end{array}$ \\
\hline $\begin{array}{l}\text { 4. With Wiki, the quality of } \\
\text { interaction with my } \\
\text { classmates and teachers was } \\
\text { better, which enhanced my } \\
\text { learning experience. }\end{array}$ & $\begin{array}{c}12.8 \% \\
(12)\end{array}$ & $\begin{array}{c}45.3 \% \\
(42)\end{array}$ & $\begin{array}{c}30.1 \% \\
(29)\end{array}$ & $\begin{array}{c}5.4 \% \\
(5)\end{array}$ & $\begin{array}{c}6.4 \% \\
(6)\end{array}$ \\
\hline
\end{tabular}

While many agreed that the online environment, in particular the Wiki learning activities and interaction, allowed more room for authentic learning experiences, some students were, as can be seen in Table 6, not entirely comfortable with sharing their homework and tutor's remarks. Others also suggested that five Wiki activities were too many:

Table 6 Excerpted student feedback on the ENGL A122F Wiki activities

\begin{tabular}{|ll|}
\hline Feedback 1. & 'It's not fair to allow students to view others' homework.' \\
\hline Feedback 2. & $\begin{array}{l}\text { 'The assignments that students do in the Wiki should not be shared among } \\
\text { students.' }\end{array}$ \\
\hline Feedback 3. & 'The comments in Wiki are rather discouraging.' \\
\hline Feedback 4. & 'Tutors instead of students should give feedback.' \\
\hline Feedback 5. & 'Less online activities.' \\
\hline
\end{tabular}

Fortunately, more than $50 \%$ of the students in the survey 'agreed' or 'strongly agreed' that the online setting and Wiki activities did encourage them to present ideas, ask questions about their own presentations, and articulate their interpretation of certain key concepts in the course. As Farmer (2005) remarks, 'technology increases opportunities and means to express facts and perspectives, and facilitates metacognitive processes; participants can transcend reactive activity and become more engaged and productive' (p. 12). To a certain extent, the blended learning approach enhanced students' presentational knowing. 
Table 7 Survey results that reflect on presentational knowing enhancement

\begin{tabular}{|c|c|c|c|c|c|}
\hline & $\begin{array}{c}\text { Strongly } \\
\text { agree }\end{array}$ & Agree & Neutral & Disagree & $\begin{array}{l}\text { Strongly } \\
\text { disagree }\end{array}$ \\
\hline $\begin{array}{l}\text { 5. With the online learning } \\
\text { platform, I became more } \\
\text { likely to ask questions. }\end{array}$ & $\begin{array}{c}8.5 \% \\
(8)\end{array}$ & $\begin{array}{c}44.7 \% \\
(42)\end{array}$ & $\begin{array}{c}19.1 \% \\
(18)\end{array}$ & $\begin{array}{c}22.3 \% \\
(21)\end{array}$ & $\begin{array}{c}5.4 \% \\
(5)\end{array}$ \\
\hline $\begin{array}{l}\text { 6. Wiki helped me present my } \\
\text { ideas and understanding of } \\
\text { the key topics. }\end{array}$ & $\begin{array}{l}16 \% \\
(15)\end{array}$ & $\begin{array}{l}34 \% \\
(32)\end{array}$ & $\begin{array}{c}35.1 \% \\
(33)\end{array}$ & $\begin{array}{c}10.6 \% \\
(10)\end{array}$ & $\begin{array}{c}4.3 \% \\
(4)\end{array}$ \\
\hline
\end{tabular}

\section{Conclusion}

The results from the post-course student survey and the evaluation report suggest that, in general, students on the ENGL $A 122 F$ course developed positive attitudes towards blended learning. With the introduction of the blended learning mode and the incorporation of peer discussion in the OLE Wiki, interpersonal connections between students, lecturers and tutors were promoted in a short period of 13 weeks. The online peer interaction, sharing and discussion brought about by the blended learning approach enriched students' learning; and propositional knowing and experiential knowing, as well as presentational knowing, were enhanced. Successful as it was, sharing their assignment online and allowing classmates to comment freely on their work were of concern to some students. As Rhea et al. (2007) argue, peer discussion does not always bring positive learning experience. In their study, it was found that about $20 \%$ of the comments made by graduate students were destructive criticism with no suggestions for improvement. In this regard, the teaching team will need to strike a balance between openness and confidentiality in the online learning environment.

\section{References}

Bath, D. \& Bourke, J. (2013). Getting started with blended learning. Griffiths University: New South Wales.

Fang, L., Chow, S. H., \& Soo, W. M. (2012). Framework for evaluating blended learning in a university public-speaking course in Singapore. In P. S. Anastasiades, Blended learning environments for adults: Evaluations and frameworks. Hershey, P.A.: Information Science Reference.

Farmer, L. S. J. (2005). Using technology to facilitate assessment of library education. Teacher Librarian, 32(3), 12-15.

Heron, J. (1992). Feeling and personhood: Psychology in another key. London: Sage. 
Heron, J., \& Reason, P. (2006). The practice of co-operative inquiry: Research 'with' rather than 'on' people. In P. Reason, \& H. Bradbury (Eds.), Handbook of action research. London: SAGE Publications.

Marsh, D. (2012). Blended learning: Creating learning opportunities for language learners. New York: Cambridge University Press.

Murphy, A. F. (2012). Bridging the 'cultural gap': The impact of arts-based content lessons on English learners. Engaging Cultures and Voices: Learning English through media, 4, 1-31.

Rhea, N., Rovai, A., Ponton, M., Derrick, G., \& Davis, J. (2007). The effect of computer-mediated communication on anonymous end-of-course teaching evaluations. International Journal on E-Learning, 6 (4), 581-592.

Solomon, G.. \& Schrum, L. (2010). Web 2.0: How-to for educators. Eugene, OR: International Society for Technology in Education (ISTE). 